\title{
Kadın Güçlendirmesi ve Toplumsal Cinsiyet Eşitliği’nin Ölçülmesi: Türkiye Örneği
}

\author{
Meltem INCE YENILMEZ*
}

\begin{abstract}
$\ddot{O} Z$
Çağdaş Türkiye'de kadın güçlendirilmesi ve cinsiyet eşitsizliğini analiz etmek oldukça önemlidir. Türkiye Cumhuriyetinin kurulmasından bu yana kadınların sosyoekonomik ve kültürel gelişimi için birçok reform gerçekleştirilmiştir. Bu reformlar bile çağdaş Türkiye'de cinsiyet eşitsizliğini ortadan kaldıramamışıtır.

Bu araştırma, Türkiye İstatistik Kurumu verilerini kullanarak ve ikili lojistik regresyon uygulayarak Türkiye'de kadın güçlendirilmesine cinsiyetçi açıdan incelemektedir. Araştırma sonuçları kadınların çalışma hayatı içerisinde olmasının, kadın güçlendirilmesi için oldukça etkisi olduğudur. Analizin bir diğer sonucu ise aynı işlerde çalışan kadınların güçlendirmesinin daha mümkün olduğudur. Bu bakımdan çeşitli mesleki özellikler bazı güçlendirme göstergeleri ile bağlantılıdır.
\end{abstract}

Anahtar Kelimeler: Kadın güçlendirmesi, toplumsal cinsiyet, cinsiyet eşitliği

JEL Sinıflandırması: C35, J01, J11, J16 \section{Turkey \\ Measuring Women Empowerment and Gender Equality: Case of}

\section{ABSTRACT}

It is very important to explore women's empowerment and gender disparity in contemporary Turkey. Various reforms have been propounded since the establishment of the Turkish Republic to promote women's socioeconomic and cultural development. Even with these reforms, gender inequality remains Turkey's contemporary challenge.

This research looks at women's empowerment in Turkey utilizing Turkish Statistics Institute data and applying binary logistic regression. The suggestions of this research is that being among the labor market is vital to women's empowerment. The findings of this analysis also shows that women in some job fields have a higher probability for empowerment. Various occupational features are linked with some empowerment indicators.

Key Words: Women's empowerment, gender mainstreaming, gender equality

JEL Classification: C35, J01, J11, J16

\section{INTRODUCTION}

There are a plethora of meaning that the term empowerment can assume, and in fact, embarking on giving a singular all-encompassing definition for empowerment would accurately be considered a Herculean task. But most generally, it refers to actions that lead to improvement in living standards; it could also be seen as the overall processes that culminates in a transformation. It could

\footnotetext{
* Doç.Dr. Meltem Ince-Yenılmez, Yaşar Üniversitesi İşletme Fakültesi, İktisat Bölümü meltem.ince@yasar.edu.tr
} 
be a goal for lots of schemes (Carolyn Medel-Anonuevo and Bettina Bochynek, 1995). Another school of thought pioneered by Nelly P. Stromquist, in 1995, sees "empowerment as the process to change the distribution of power both in interpersonal relations and institutions throughout society". And Naomi Klein decribes the injunction of Nike, "just do it", as a true message of empowerment. However, one all encompassing definition of the term was due to Lucita Lazo, in 1995, that describes empowerment as a process of gathering, making available, distributing valuable materials, resources and the means, or creating room for individual to have dominance over such assets."

One would gain more clarity on Stromquist's school of thought on empowerment by first learning about the revolutionary trends that led to very concrete empowerments. In the opinion of Stokeley and Hamilton (1967), the American civil rights movement (which spanned the 14-year period of 1954 to 1968), is one fundamental origin of empowerment. The phenomenon of racial segregation and gender discrimination was the stirrer of the movement, as many members of the black race began an agitation. According to them, it became imminent for "black people to come together, recognize their heritage, build a sense of community, pursue a specific course, link their own organizations, and support these organizations".

In less than a decade after the African American civil rights movement, the notion of empowerment crept into the scenes of gender, as observable levels of intimidation were noticed to face women. A major outplay that indirectly aggravated the ongoing oppression was the inability of leaders and those in power to recognize the ill of the situation or need to make amends alltogether (Tuna, 2012). It became imperative for the victims to take the challenge of struggling for their self-emancipation and create the utopia they seek.

It is commonplace to have men weigh more on the societal sclaes of influence and percieved relevance. Women have somehow found themselves on the recessive end of most institutions from traditions that consider a female child a less favorable omen relative to their male counterparts, to political appointments, family position, legal protection, and even in academics. And to make matters worse, the prevailing position of things surrounding the less regards for women on these key aspects is percieved the standard of natural order. In light of the foregoing, we easily fit in Stromquist's earlier highlighted perspective on empowerment as "the possession of new knowledge to create a different understanding of gender connections and distabilizing the conventional beliefs that had hampered a group of individuals from thriving at all societal levels". Women must in this spirit realize that just as men, they are beyond mothers and wives, they are changemakers and drivers of the society as well. They would have to pick up similar mantles that were picked in Southern America in the late 1950s and cause a revolutionary change, a change that should shake global policies on issues pertaining to gender equality.

Given the opinions on empowerment, the underlying notion is the prevention of a group of individuals from entering the central spotlights in a 
number of major institutions. The group of people might be undergoing the segregation based on race, language, level of education, wealth, and other basis. It should be noted that the varied perceptions of empowerment are shaped by diverse cultures, experiences, and revolutions. But in this article, we would take our major cues from the empowerment of women in Turkey; we consider the standing of women in the Middle East country, Turkey.

In this work, roles played by a number of factors on the empowerment of Turkish women will be examined. The fundamental parameters that had to be tweaked in order for the current state of women in turkey to be attained, whether demographic, cultural, or religious will be analyzed. In this paper, the intricate dynamism of family relationships that lead to women being dominated by their male relatives and other crucial decisions are explicitly considered.

\section{A JOURNEY THROUGH THE ROAD OF GENDER EQUITY IN TURKEY}

Stretching as far as 300 years ago, during the Turkish Ottoman Empire, minor moves towards bridging gender differnces had begun. After being possibly inspired by some dream, Osman founded the Ottoman Empire. But soon the Empire began to experinec the reign of really young sultans such as Osman II who was barely 14 years old when he succeeded his father Mustafa I who also was 26 years in his first reign. Being that these sultans were rather more naive than they were politically experienced, they got to be influenced by thier wives or mothers in many aspects of decision-making; and in fact the women seemed a sort of pseudo-sultanate. Several changes met the Ottoman Empire as the Tanzimat reformations between 1839-1876 kicked off, championed by a number of reformist sultans like Abdulmecid I and his father Mahmud II. In the same century, the empire experienced a vibratory revolution as educated Turk women increased in number and began to take a feminist stand demanding women emancipation in forms such as equal civil rights, discouragement of practises like polygamy, equal job opportunities amongst others. This collective pursuit extended its horizons to the media as well, gaining major spots of attention in magazines, which all culminated in the setting up in the first decade of the 20th century the Ottoman Welfare Organization of Women (OWOW). Recording the membership of influencial figures like Halide Edip Adivar who painted the unfortunate picture of women's social position with his writings, Nezihe Muhiddin, and Fatma Aliye hanim who was a Turkish novelist and women's rights activist (Gündüz, 2012).

The Revolutions which began in the 19th century in the Tanzimat reforms soon grew into Kemalism in the first quarter of the 20th century so that by october 29th 1923, the Turkish republic came to being. As Kemalism embraced western cultures and secularity, it easily catalyzed the movements of feminism and in no time polygamy was abolished, and the law protected women on the issue of inheritting properties and divorce, as well as equal rights with the men on issues of politics. But there was still an informal margin betwenn the women and the men folks even with the picture of things, there was still some missing bricks to 
bridge the gaps. About58 years after the Turkish republic, Turk women improved their stand against the oppression and developed a keener reading culture and inquired much about feminism from books, discussed their findings, and unlocked themselves from much ignorance. The aftermath of these were realizations of the ills associated with certain gender-motivated roles hung on women, and they staged the very first protest in 1987 demanding the quick stoppage of activities that harrass women sexually or violent in nature towards women, establishing the level of sovereignty a woman hould have over herself (Gündüz, 2012).

The persistence of the women soon earned them the ears of the political leaders of the day who went on to integrate the women;s demand into the Five Year Eevelopment Plan (FYDP) of 1985-1990. As a consequence, a branch of the administration was set up at the end of the FYDP specifically burdened with ensuring that the rights of women are not toyed with, on the political, religious, social, and cultural sphere. Just three years after this action in 1990, a woman emerged the Prime Minister of Turkey, making a new history for the Republic. During that period, the ideas and teachings of feminism was gaining deeper roots in the Turkish institutions.

Researches showed that the degree and phenomenon of women persecution can hardly be disconnected from the existing traditional beliefs and misconceptions about women (Yorgun, 2013). The women themselves have gotten so engrossed in the beliefs that they repel their own liberation through the actitude of condemning feminism; the Turk women have grown to percieve their social and economic status as a natural norm that should not be altered by the secular philosophies preached by feminists. Further researches due to Anikan, in 2013, also went on to elucidate the scale to which gender inequality has crept into the academic sphere. He stated that the supposed equality that is sometimes claimed does not transcend beyond the papers, pointing out the manner in which male students outnumber the female ones, and study farther than them.

On the other hand, the patriarchal nature of the Turkish society influences the participation rate of women in employment. Household and family life is where women's subordinate status and violence against women is best observed. While the republican reforms provided the legal and institutional structures for the termination of sex segregation and unequal treatment of women under the law, they did not necessarily produce comparable changes in life-style (Olmsted, 2011). The role of women as mothers and housewives limits their work outside of the home. Society's expectation of men to be the breadwinners of the household further limits women's labour participation outside the home (Ilkkaracan, 2012). As a result, the participation of women especially in rural areas in the country's labour market is among the lowest in the world. The status of women in the workplace is another bleak territory in a country whose economy is liberal and whose corporations strive to be competent on a global scale. Corporate senior administrators often see the need to embrace a global corporate culture, which is predominantly "western", but when it comes to the rights of women in the 
workplace, they simply embrace traditional values on a local level. Transnational corporations have absolutely learned to adapt to local markets, however, when it comes to culture, they often use the culture of locals to achieve their own ends relentlessly. A study on the relations among family members and gender roles in households in Turkey reveals that the ratio of engagement of women to men in domestic tasks such as doing the laundry and dishes, for example, is approximately 85 percent to 3 percent respectively. The research shows that the higher the education level of women, the less she is involved in domestic tasks. This research further highlights that in the words of Basak, Kingir and Yasar, "a democratization in the private sphere could be attained through a more egalitarian sharing between spouses," also suggesting that change could arrive by transforming the long established "cultural perception of women as 'serviceproviders' and men as those served" (Editorial, 2013).

A careful retrospection of the works on empowerment of Turkish women indicates that the equality of women and men was a theoretical mirage that was far from the reality. There are some factors that indeed made it difficult for the state of liberty and prestige for women to be actualized and among them are the low level of education and weak professional strenght that has impeded the necessary transformation that women in Turkey really needed. This work is precisely based on shedding finer light on these challenges.

\section{THE SITUATION SINCE 2002}

Turkey strived to earn a place among the member states of the European Union in 2004, and this step has led to a sort of necessitation on their part to adopt the Acquis Communaire of the European Union that contains the directives and regulation that member states must comply with, enunciated since 1958. Endorsed by the laws in this scheme are those that protect the rights of every member of the society irrespective of gender; there is a mandatory policy of legal equivalence that must be respected. The effectiveness of these laws are still in view, but they would be completely in play when the rights of every individual is not slightly tampered with.

The Law 5840 on Equal Opportunities commission for Women and Men became a constitutional policy by the second month of 2009 in Turkey. By the next month, the commision assume the responsibilty of ensuring that rights of every citizen is protected in the areas of law making irrespective of the gender. To hit the hammer on the nail, the newly established commision was saddled with the key role of ensuring that gender balance is a reality in all institutions, an d ensuring as well that through the eyes of the government there are neither male nor female, only equal citizens.

In recent years, Turkey has been going through many structural and social changes. These changes would have been expected to facilitate more women to enter the labour market. Part of this sociocultural may be due to the changing economic conditions. It is a lot harder for a single income source to cater for the family need so that the society is now getting used to seeing women working especially in urban areas. Additionally, women are getting more education 
(UNDP, 2014). In the past two decades, the number of illiterate women dropped from $33.9 \%$ to $19.6 \%$, while the proportion of women with more than primary school education more than doubled. Also, the share of women with university education increased from $1.8 \%$ in 1988 to 11.7 in 2014 . A more educated female population is likely to have positive effect on their employment since higher education is associated with increased participation in the labour force. Women are getting married at a later age compared to earlier generation. This allows them to study and participate in labour force. Fertility rate is also on the decrease. In 2008, women were expected to give birth to 1.9 million children as against the 5.7 million and 3 million in 1963 and 1988 respectively. It is therefore baffling to see the number of women having jobs still low (TurkStat, 2016).

Women's empowerment generally involves a series of social and economic aspects. Consequently, to understand the barriers to and the motivation for empowerment, it is important to look at the economic and social framework of the Turkish households, how gender relations in and outside the households are produced and re-enacted in Turkish society. Traditional roles in Turkey in addition to intra-family roles are important determinants of womens' choices. Therefore, the low rate of women in the labour market needs to be examined from both an economic and a sociocultural viewpoint. Also, the effect of husband's employment situation on wife's participation is also a good indicator of women's empowerment. According to the "added worker effect" hypothesis, wives, inactive in the labour market, decide to temporarily participate in order to compensate for the loss of income due to husband's unemployment (Kalb, 2009). On the other hand, being married and having children negatively affects women's empowerment due to their housekeeping chores and childcare responsibilities. Especially, a childcare responsibility is more crucial who has children below seven age and school age children between ages of seven and fourteen (DayığluKasnakoğlu 1997). The idea that young children may suffer if their mother works is relatively wide spread in all countries and has an impact on women's empowerment of a child bearing age ( 25 to 44 years) (TUIK, 2016). They re-join only later in life, when their children are old enough to take care of themselves (Kızilırmak, 2005).

\section{INVESTING IN WOMEN'S ECONOMIC EMPOWERMENT}

Investing in women's economic empowerment is an important step towards women's participation in the formal sector of the economy. Turkish women's participation in the labour market remains low (36.6\% against the EU's average of $58.6 \%$ ), and is one of the lowest in OECD countries. The female employment rate remained very low at around $30.6 \%$ in 2016, although it was up by $1.1 \%$ on the preceding year. Despite the low proportion of the female population actively looking for work, the female unemployment rate is higher than the male. There is a labour divide as women are mainly in agriculture and/or other low income or unpaid jobs. About one third of women, who are employed, are unpaid family workers in the agricultural sector (Ecevit, 2003). 
To solve this problem, the country really needs to get more women into the labour market, into well paid professions with good working condition in line with the agenda of the International Labour Organization (ILO) and the European Union (EU). The country needs to embrace innovations that promote women's economic resilience; innovations that will help women overcome the barriers of livelihood and promote a more equitable income flow of financial and nonfinancial benefits. This could be in the form of promoting women's entrepreneurship and providing female entrepreneurs with credit facilities and vocational training while supporting organizations that do the same. Once women have increased control of resources, it will give them a level of confidence they need to make necessary contributions to the household, economy, their reproductive health, etc.

For instance, improvements in women's employment in the private sector could be achieved by remedying the shortfall between the skills taught at school and those required in the labour market, guaranteeing equal access to quality learning, fostering women's education and training in science and technology universities and similar centres, introducing on-going learning programmes for women and encouraging private enterprises to launch training programmes for women graduates, encouraging the private sector and foundations to invest in programmes and the improvement of skills to favour women's enterprises and career opportunities for women and girls, and supporting recruitment, retention and progress of women and girls in the fields of science, technology and innovation by means of transparent criteria (Ecevit, 2003).

Women face more challenges in business life and in their professional careers, but drawing up rules on gender equality and closely following their implementation in the company are the keys to closing the gender gap. Measures to prevent gender discrimination in recruitment and promotions must be put in place and their implementation should be closely followed. In recent years the government has also encouraged female employment in the private sector (Betcherman, Luinstra, and Ogawa, 2001). For instance, since 2008, the government has offered to pay a company's share of female employees' social security benefits for 54 months if it hires women who have been unemployed for six months or longer. Meanwhile, Turkish Employment Agency (ISKUR, 2016) also supports women by offering training courses in various fields of occupation, including computer management, programming, sales, and so on. Some of these policies have prominently influenced the female employment rate, which, while very low, has been steadily rising in the last decade from $23.3 \%$ in 2004 to $29.5 \%$ in 2012, as confirmed in the 2013 report of the Turkish Statistical Institute (TurkStat, 2016). To maintain this trend and achieve $35 \%$ female employment by 2023, the Turkish government has recently implemented new policies, such as an 18-week maternity leave, a flexible part-time working model and the establishment of workplace day care centres to allow women to work while starting families. However, some still remain sceptical about the feasibility of the government's $35 \%$ objective - despite the fact that it is only a six-percentage- 
point increase, the same that occurred in Turkey between 2004 and 2012 (World Economic Forum, 2014).

Creating new employment areas and ensuring that they are open to women have been the fundamental responsibilities of the state and the private sector. In this regard, active employment policies devoted to the mitigation of unemployment should be designed, and a comprehensive women's employment policy should be incorporated. A plan comprised of concrete and time-limited targets should be made to implement these policies in a timely manner. Related institutions and mechanisms should be provided with sufficient funds and human resources, via allocated funds from the budget, to enable them to implement the equality policies that will be determined. Public and private sector institutions should develop active mechanisms that will ensure the questioning and transformation of gender-based discrimination that women are subjected to in every aspect, such as employment, vocational training and promotion, to ensure gender equality and to struggle against all kinds of discrimination. Labour relations in the Labour Code should be defined to include an engagement process to eliminate discrimination during the recruitment process. Strengthening preschool education and increasing enrolment rates will help promote women's participation in the workforce through improved childcare services.

Economically empowered women can promote the development of a nation. Such women are likely to have fewer children and fertility rates discussed so far indicate this. Such women (unlike their male counterparts) are likely to defy the patriarchal system in operation by giving their sons and daughters equal opportunities to attain education. They can promote better environmental sustainability. If the society can view the benefits from this perspective, it will understand the need for women's education and empowerment; it will realize that not only is it a matter of a human right, but also of human security. So unless women are economically empowered, Turkey will continue to grapple with poverty and gender inequality.

The country, which aims to be among the top 10 world economies in 2023 (World Economic Forum, 2014), needs to mobilise all its human potential. A comprehensive approach is needed, which includes measures to ensure better working conditions, equal pay for equal work, lifelong learning, flexible work schedules and a fair balance between family life and work. Efforts to ensure better working conditions should encompass measures to combat all forms of discrimination at home and in the workplace, including gender discrimination in recruitment, promotion and benefits.

\section{BODY OF RESEARCH AND METHODOLOGY}

In the course of the latter sections, it has been repeatedly stated that the objective of this paper is to analyze socio-economic and demographic parameters in the light of how much contribution they make to the empowerment of Turkish women. The approach we would use to achieve that goal is a binary logistic regression model. In this model, the various categorical parameters and other control variables that influence the status of women are sorted in separate 
categories. One favorable characteristic of the logistic modeling approach is its capacity to relieve analysts of problems that arise from data insufficiency that could easily mar the entire analysis, its ability to manage such situation. This model works in such a way that its structure is subjective, and depends on the number of specified unknowns and parameters. Now one easily identifies the difficulty associated with attempting to tag levels of empowerment with numerical values, and this makes for a heightened level of perplexity for researchers on the concept. Significant weight was placed on such parameters as degree of participation in decision making and managing of finances, as well as workplace dominance and scales of other social liberties. Although efforts were made to exclude subjective dispositions in this study, it came in at points where individuals failed declined at responding to enquiries made of them; such individuals were quickly removed as informative sources in the work.

Concerning the way of logistic regression, every single variable is coded so that a one (1) connotes concurrence with unequal women economic empowerment in Turkish economic way of life. Hence, odd proportions that are over an estimation of one (1) mean a positive relationship between the indicator variable and the poor variable. By differentiation, odd proportions that are underneath an estimation of one (1) imply a negative relationship between the indicator variable and the subordinate variable. For example, we can characterize: inspect dissect method ability. Unsubstantiated

$$
\mathrm{y}_{\mathrm{i}}=\left\{\begin{array}{l}
1 \text { if the } i^{\text {th }} \text { women are willing to be in economic life in Turkey } \\
0 \text { otherwise }
\end{array}\right.
$$

$\mathrm{y}_{\mathrm{i}}$ can be viewed as realization of a random variable Yi that takes the values of " 0 " and " 1 " with probabilities $\Pi_{i}$ and $1-\Pi_{i}$. Note that if $y_{i}=1, \Pi_{i}$ is obtained, if $\mathrm{y}_{\mathrm{i}}=0,1-\Pi_{\mathrm{i}}$ is obtained. Therefore,

$$
\begin{aligned}
& \mathrm{P}_{\mathrm{i}}=\mathrm{E}\left(\mathrm{Y}=1, \mathrm{X}_{\mathrm{i}}\right)=\beta_{1}+\beta_{2} \mathrm{X}_{\mathrm{i}} \\
& \mathrm{P}_{\mathrm{i}}=\mathrm{E}\left(\mathrm{Y}=1, \mathrm{X}_{\mathrm{i}}\right)=\frac{1}{1+\mathrm{e}^{-\left(\beta 1+\beta 2 X_{i}\right)}} \\
& \mathrm{P}_{\mathrm{i}}=\frac{1}{1+\mathrm{e}^{-\mathrm{Zi}}} \begin{array}{c}
\text { Where } \mathrm{Z}_{\mathrm{i}}=\beta_{1}+\beta_{2} \mathrm{X}_{\mathrm{i}} \\
\text { Whe }
\end{array}
\end{aligned}
$$

The most obvious idea to make it linear function of $X$, logarithms of the two sides must be taken. As a result, the logistic regression model is:

$$
\mathrm{Li}=\log \stackrel{\mathrm{P}_{\mathrm{i}}}{=}=\alpha_{\mathrm{i}}+\beta_{1}+\beta_{2} \mathrm{X}_{\mathrm{i}}
$$

$\frac{P_{i}}{1-P_{i}}$

$$
1-\mathrm{P}_{\mathrm{i}}
$$

$1-\mathrm{P}_{\mathrm{i}}$
represents the log-odds. 
A number of studies in this aspect, including those of the Turkish Statistical Institute (TUIK) have been nanlyzed using the logistic regression models. The analysis itself is designed in such a way that $\mathrm{t}$ adopts a unique probability technique on individual that are or above 15 years of age. The variables span parameters that are population-oriented or economically based; and the variables are categorised as dependent or independent. With the chosen sample, the results are assumed to capture what would be expected of the adult Turkish population. In a similar fashion, a portion of the entire Turkish population was considered as a sample to extract the data expected of the whole. And when the situation entails handling attributes that are not present in the members of the sample, other attributes are substituted for consideration. The approach here involves indicators sorted out from a sampling of both dependent and independent variables (Allison, 2002; King et al., 2001).

Being that the goal has been conveniently under the aspects of empowerment of Turk women in the institutions of academics, labour, marriage, and age, this research paper has taken these four parameters as fundamental variables to be used. In order to scientifically quantify liberties, a sclae was developed to grade the degree of responses recieved from women. The scale is fashioned from zero to 1 capturing the graduated degree of the response; for instance, "do you vet decisions made by your spouse?" can be answered either in the affirmative or otherwise. Any fuzzy response would then be lying between 0 and 1 , and can accurately be seen loosely as extents of empowerment. From the investigation, almost $77 \%$ of the women in Turkey responded in the affirmative to the question "are you in active demand of economic empowerment?". Then to evaluate the degree of empowerment in the aspect of decision making, two or ore parameters involving decision making role are considered, and afterwards the grade is averaged. If the final grade lies closer to 1 than 0 , then such a woman is favorably involved in active decision making.

The key question used to extract the strength of decision making of the women is "does any male relative of yours play a role in deciding how you should shape your work life?" To this question they could answer "yes", "no", while others admitted a collaboration in the decision making. However the study shows that as to willingness to be an active player in the work force, 7 of every 10 Turkish women responded in the affirmative. As to how their residential environment motivates their empowerment, the question that served as a tool of measurement was "does your residence position you for the best work opportunities?" Again the expected responses are either "yes" or "no". Women in the more civilized areas of Turkey were more on the affirming end to this question as compared to the ones in rural areas, with the data of slightly over $81 \%$ correlating finely to this conclusion.

One fundamental determinant that tells high level empowerment is managerial roles over resources (Kabeer, 1997). The varaible utilized in this study to check to what levels of control the women had over their funds and resources 
was the question "do you have the liberty to have separate finances and resources?" There is a clearly observable distinction between managing the family assets and owning personal resources. There is a huge gap of empowerment bridged when women own their personal resources separate from that of the entire house. The response of the Turkish women to this variable was over $82 \%$ in the affirmative, which is a strong mark that empowerment has already gained substantial roots.

\section{A. Financial Control Variables}

The major independent variable of the examination; employment, is a dichotomous variable with 0 alluding to not working and 1 alluding to working. Since there is a rhetoric link between employment and empowerment, a great many women shape their lives depending on the dimensions of occupations. The financial logical attributes for the gender crevice in economic investment that are presented are work status, per capita income, livestock ownership and land ownership. Income is a ceaseless variable and alludes to the respondents' impression of their profit. It ranges between $(=0)$ most minimal and (=9) most astounding. Work status is a trivalent variable showing whether an individual is as of now (=2) not employed; (=1) housewife; or $(=0)$ employed. Ownership of a property can raise women's chance to invest in various income generating assets. Livestock ownership and land ownership variables are computed by asking women about any property they have in their possession and it is " 1 " if woman has an ownership and " 0 " otherwise.

\section{B. Demographic Control Variables}

In addition to the employment variables, a few main socio-demographic characteristics are included as control variables. Education alludes to the finished education level and it is measured by four categories: $(=3)$ primary; $(=2)$ secondary; $(=1)$ higher, and $(=0)$ tertiary. Women's economic empowerment is well influenced by age. Therefore, the variable of age is continuous and it is hypothesized that there might be higher levels of women's economic empowerment among women in the older age group. The respondents are recognized as "15-24" (=0), "25-39" (= 1), "40-64" (= 2), and "65 or more" (= 3). Family size is an additional societal factor, which determines women's economic empowerment. In most of the big size families, higher aged members of household make larger evaluation. However, in nuclear families women can work independently in domestic activities. A dummy variable is used for family size as " 1 " if woman lives in a large family and " 0 " otherwise. Marital status is coded to distinguish respondents as "single" (=0); "married" (= 1) or "other" (e.g., separated, divorced or widowed) $(=2)$. In conclusion, number of youngsters is dealt with as a continuous variable, extending from "no kids" $(=0)$ to "four or more kids" (=4). In Turkey, because of undetermined dominant patriarchal rules over women and their positions in the society, males are heads of the household and female headship is not acknowledged culturally. It is expected that women's economic empowerment is negatively related to husband's headship if husband makes most of the household decisions alone without engaging women. 


\section{Results}

Model 1 only contains demographic variables, while Models 2 shows demographic and financial control variables in the regression. Then, Model 3 shows female occupations where Model 4 studies all indicator variables included in the research. Table 1 shows the relationship between occupations, demographic and financial control variables, freedom of rights, and agreement with the assertion that education is very important for women's empowerment in the labour market. The results from the logit reveal that freedom of rights in work life has a huge effect on women's empowerment. The positive significant coefficient shows that workingwomen have high chance of having higher empowerment figures. There is a strong connection between women's empowerment and education level where education is shown to be directly influenced by women's freedom of rights and the women who have freedom of rights when it comes to decision making have about 2.18 times more chances of being able to complete their schooling or do not require permission to complete their education. Consequently, by calculations in Model 1 of Table 1, the probability of this happening are higher for women who are educated than for those who aren't $(\mathrm{OR}=2.18, \mathrm{p}<0.01)$. Model 2 demonstrates that the likelihood of support for women's empowerment is immensely influenced with whether they are employed or not employed $(\mathrm{OR}=3.12, \mathrm{p}<.05)$. In Model 3, while it can be seen that the increases are a bit little for the women who are skilled, it also shows that women with better occupations, have a higher probability of enjoying more freedom of rights. Also, socio-demographic indicators are great influencers to the chance of rights. The totality of these findings continue when all the variables for control are included in Model 4, with a little decrease in the probability of assertion and criticalness level for educated women $(\mathrm{OR}=1.95, \mathrm{p}<.05)$.

Table 1: Logit Model Predicting Freedom of Movement by Financial, Demographic and Occupational Characteristics

\begin{tabular}{lcccc}
\hline Variable & Model 1 & Model 2 & Model 3 & Model 4 \\
\hline Demographic measures & & & & \\
Primary education (omitted = tertiary) & $1.27^{* *}$ & $1.22^{* *}$ & $1.21^{* *}$ & $1.17^{* *}$ \\
Secondary education (omitted = tertiary) & $1.92^{* *}$ & $1.84^{* *}$ & $1.84^{* *}$ & $1.83^{* *}$ \\
Higher education (omitted = tertiary) & $2.18^{* *}$ & $2.18^{*}$ & $2.16^{*}$ & $1.95^{*}$ \\
Age 15-24 (omitted = 65-older) & $.288^{* * *}$ & $.279^{* * *}$ & $.256^{* * *}$ & $.231^{* * *}$ \\
Age 25-39 (omitted = 65-older) & $.325^{* * *}$ & $.319^{* * *}$ & $.301^{* *}$ & $.299^{* *}$ \\
Age 40-64 (omitted = 65-older) & $.704^{* *}$ & $.708^{* * *}$ & $.715^{* * *}$ & $.718^{* * *}$ \\
Married (omitted= Single) & $1.43^{* *}$ & $1.48^{* *}$ & $1.41^{* *}$ & $1.38^{* *}$ \\
Married (omitted= Other) & $1.27^{* *}$ & $1.27^{* *}$ & $1.33^{* *}$ & $1.33^{* *}$ \\
Urban (omitted= Rural) & $1.47^{* *}$ & $1.45^{* *}$ & $1.45^{* *}$ & $1.42^{* *}$ \\
Rural (omitted= Urban) & $-.719^{* *}$ & $-.712^{* *}$ & $-.708^{* *}$ & $-.703^{* *}$ \\
Large family size (omitted= otherwise) & $-.072^{* * *}$ & & & \\
Children & $1.34^{* * *}$ & & & \\
\hline Financial Measures & & & & $1.55^{* * *}$ \\
Income & & $1.78^{* * *}$ & & $2.83^{* *}$ \\
Employed (omitted = unemployed) & & $3.12^{* *}$ & & $.1 .17^{* *}$ \\
Unemployed (omitted = employed) & & $1.65^{* *}$ & & $.653^{* * *}$ \\
Housewife (omitted = employed) & & $.813^{* * *}$ & & \\
496 & & & &
\end{tabular}




\begin{tabular}{|c|c|c|c|c|}
\hline \\
\hline \multicolumn{3}{|l|}{ Not Working } & Omitted & Omitted \\
\hline \multicolumn{3}{|l|}{ Professional/Managerial } & $.689 * *$ & $.435 * *$ \\
\hline \multicolumn{3}{|l|}{ Service } & $.677 * *$ & $.589 * *$ \\
\hline \multicolumn{3}{|l|}{ Household } & $.288 * *$ & $.217 * *$ \\
\hline \multicolumn{3}{|l|}{ Skilled manual } & $.471 * *$ & $.219 * *$ \\
\hline \multicolumn{3}{|l|}{ Unskilled manual } & $.198 * *$ & $.157 * *$ \\
\hline \multicolumn{3}{|l|}{ Agricultural } & $.273 * *$ & $.115^{* *}$ \\
\hline Likelihood ratio $\mathrm{X}$-square & 74.168 & 47.197 & 193.285 & 166.193 \\
\hline (-2 log likelihood) & 1604.227 & 1431.283 & 1379.194 & 1128.152 \\
\hline Weighted N & 1450 & 1450 & 1450 & 1450 \\
\hline
\end{tabular}

Model 1 in Table 2 proves the positive relationship between women's empowerment and marital status. This particular model, forecasts that the rate of women in urban areas with higher education has centrality levels. Also, table 2 displays results on the statement that men are preferred as professional heads over women across various occupations. In this particular table, critical results are observed for educated individual, skilled variable, with the likelihood of assertion increasing by 86 percent for educated women in comparison with uneducated women $(\mathrm{OR}=1.86, \mathrm{p}<.01)$. These chances of understandings were lower however huge for uneducated women $(\mathrm{OR}=1.54, \mathrm{p}<.01)$ and $(\mathrm{OR}=1.62, \mathrm{p}<$ $.01)$. Model 3 puts forward the suggestion that occupation is connected with women's decision-making. For decision-making in women, the coefficients shows that women who work in technical/professional/ managerial, in sales/services, in clerical, and also in household have a higher chance of opportunities to make decisions than women in other fields of work. In Model 4, no significant relationship was produce by any other control variables.

Table 2: Logit Model Predicting Decision-Making by Financial, Demographic and Occupational Predicts Characteristics

\begin{tabular}{lcccc}
\hline Variable & Model 1 & Model 2 & Model 3 & Model 4 \\
\hline Demographic measures & & & & \\
Primary education (omitted = tertiary) & $1.54^{* *}$ & $1.47^{* *}$ & $1.45^{* *}$ & $137^{* *}$ \\
Secondary education (omitted = & $1.62^{* *}$ & $1.62^{* *}$ & $1.46^{* *}$ & $1.43^{* *}$ \\
tertiary) & $1.84^{* *}$ & $1.77^{* *}$ & $1.75^{* *}$ & $1.68^{* *}$ \\
Higher education (omitted = tertiary) & $.154^{* * *}$ & $.148^{* * *}$ & $.134^{* * *}$ & $.129^{* * *}$ \\
Age 15-24 (omitted = 65-older) & $.278^{* * *}$ & $.271^{* * *}$ & $.249^{* *}$ & $.237^{* *}$ \\
Age 25-39 (omitted = 65-older) & $.810^{* *}$ & $.796^{* * *}$ & $.755^{* * *}$ & $.736^{* * *}$ \\
Age 40-64 (omitted = 65-older) & $1.26^{* *}$ & $1.23^{* *}$ & $1.18^{* *}$ & $1.09^{* * *}$ \\
Married (omitted= Single) & $.699^{* *}$ & $.664^{* *}$ & $.648^{* *}$ & $.599^{* *}$ \\
Married (omitted= Other) & $1.25^{* *}$ & $1.23^{* *}$ & $116^{* *}$ & $1.07 * *$ \\
Urban (omitted= Rural) & $-.488^{* * *}$ & $-.431^{* * *}$ & $-.427^{* * *}$ & $-.424^{* * *}$ \\
Rural (omitted= Urban) & $-.072^{* * *}$ & & &
\end{tabular}




\begin{tabular}{|c|c|c|c|c|}
\hline \multirow{2}{*}{\multicolumn{5}{|c|}{$\begin{array}{l}\text { Children } \\
\text { Financial Measures }\end{array}$}} \\
\hline & & & & \\
\hline \multicolumn{2}{|l|}{ Income } & $1.287 * * *$ & & $1.279 * * *$ \\
\hline \multicolumn{2}{|l|}{ Employed $($ omitted $=$ unemployed $)$} & $1.560^{*}$ & & $1.504 *$ \\
\hline \multicolumn{2}{|l|}{ Unemployed (omitted = employed) } & $.561 * *$ & & $.497 * *$ \\
\hline \multicolumn{2}{|l|}{ Housewife (omitted = employed) } & $.460 * * *$ & & $.358 * * *$ \\
\hline \multicolumn{2}{|l|}{ Ownership of property (omitted= otherwise) } & $1.35^{* *}$ & & $1.17 * *$ \\
\hline \multicolumn{5}{|l|}{ Occupations } \\
\hline Not Working & & & Omitted & Omitted \\
\hline Professional/Managerial & & & $.547 * *$ & $.394 * *$ \\
\hline Service & & & $.489 * *$ & $.317 * *$ \\
\hline Household & & & $.317 * *$ & $.280 * *$ \\
\hline Skilled manual & & & $.258 * *$ & $.215^{* *}$ \\
\hline Unskilled manual & & & $.088 * *$ & $.0653 * *$ \\
\hline Agricultural & & & $-.091 * *$ & $-.049 * *$ \\
\hline Likelihood ratio X-square & 41.775 & 45.980 & 115.109 & 148.5093 \\
\hline (-2 log likelihood) & 1709.807 & 1671.274 & 1627.192 & 1605.904 \\
\hline Weighted N & 1450 & 1450 & 1450 & 1450 \\
\hline
\end{tabular}

$* \mathrm{p}<.05, * * \mathrm{p}<.01, * * * \mathrm{p}<.001$

Model 1 in Table 3 demonstrates that, generally, women living in rural areas are basically more prone to earning less income than their counter parts in urban areas. Consequently, a substantial gender gap in empowerment occurs as a result of women undetectable stance in working life. The women who do manual and agricultural jobs have shown constantly to be the least empowered, nevertheless their employer also influences this. For example, women who work for people who they aren't related to have a higher chance of income than either those who are self-employed or those working for their family. One of the significant discoveries made is the big difference in marriage status and age level by socio-demographic background for women in rural areas not minding their occupation and type of work. For instance, for women working in the agricultural sector for a person who is not a family member, the chance of income is greater than rural women, not old and without education to women who are older, more educated and urban. Results as shown by Table 3, show that areas where the women live have an impact on their well-being, the control figures, that are critical, income $(\mathrm{OR}=1.14, \mathrm{p}<.05)$ and educational level $(\mathrm{OR}=1.68, \mathrm{p}<.01)$. Hence, this paper further supports either sociological methodologies (such as Burns et al., 2001) or post-modernization hypothesis (like Inglehart, 1997) to observe how financial and demographic indicators have huge effect on women's empowerment and gender balance too. 
Table 3: Logit Model Predicting Place of Residence by Financial, Demographic and Occupational Characteristics

\begin{tabular}{|c|c|c|c|c|}
\hline Variable & Model 1 & Model 2 & Model 3 & Model 4 \\
\hline \multicolumn{5}{|l|}{ Demographic measures } \\
\hline Primary education (omitted $=$ tertiary) & $.685^{* *}$ & $.674 * *$ & $.671^{* *}$ & $.657 * *$ \\
\hline Secondary education (omitted $=$ tertiary) & $.918 * *$ & $.891 * *$ & $.879 * *$ & $.873^{* *}$ \\
\hline Higher education (omitted $=$ tertiary) & $1.68 * *$ & $1.62 * *$ & $1.61 * *$ & $1.57 * *$ \\
\hline Age $15-24$ (omitted = 65-older) & $1.28 * * *$ & $1.21 * * *$ & $.992 * * *$ & $967 * * *$ \\
\hline Age $25-39$ (omitted $=65$-older) & $.897 * * *$ & $.889 * * *$ & $.886^{* *}$ & $.870^{* *}$ \\
\hline Age 40-64 (omitted = 65-older) & $.698 * *$ & $.676^{* * *}$ & $.665 * * *$ & $.647 * * *$ \\
\hline Married (omitted= Single) & $1.03 * *$ & $.887 * *$ & $.876^{* *}$ & $.869 * *$ \\
\hline Married (omitted= Other) & $.809 * *$ & $.785 * *$ & $.730 * *$ & $.726^{* *}$ \\
\hline Urban (omitted= Rural) & $1.97 * *$ & $1.88 * *$ & $1.83 * *$ & $1.83^{* *}$ \\
\hline Rural (omitted= Urban) & $-.586^{* *}$ & $-.485 * * *$ & $-.482 * * *$ & $-.469 * * *$ \\
\hline Large family size (omitted $=$ otherwise) & $.093 * * *$ & & & \\
\hline Children & $1.08 * * *$ & & & \\
\hline \multicolumn{5}{|l|}{ Financial Measures } \\
\hline Income & & $1.14 *$ & & $1.08 * * *$ \\
\hline Employed (omitted = unemployed) & & $1.847 *$ & & $1.638^{*}$ \\
\hline Unemployed (omitted = employed) & & $1.21 * *$ & & $1.16^{* *}$ \\
\hline Housewife (omitted = employed) & & $1.13 * * *$ & & $1.05 * * *$ \\
\hline Ownership of property (omitted $=$ otherwise) & & $1.73 * *$ & & $1.55 * *$ \\
\hline \multicolumn{5}{|l|}{ Occupations } \\
\hline Not Working & & & Omitted & Omitted \\
\hline Professional/Managerial & & & $.695^{* *}$ & $.398 * *$ \\
\hline Service & & & $.793 * *$ & $.578^{* *}$ \\
\hline Household & & & $.452 * *$ & $.374 * *$ \\
\hline Skilled manual & & & $.268 * *$ & $.199 * *$ \\
\hline Unskilled manual & & & $.162 * *$ & $.088^{* *}$ \\
\hline Agricultural & & & $.209 * *$ & $.155^{* *}$ \\
\hline Likelihood ratio $\mathrm{X}$-square & 3.805 & 19.674 & 25.668 & 22.704 \\
\hline (-2 log likelihood) & 1819.557 & 1882.793 & 1601.980 & 1587.102 \\
\hline Weighted N & 1450 & 1450 & 1450 & 1450 \\
\hline
\end{tabular}

$* \mathrm{p}<.05, * * \mathrm{p}<.01, * * * \mathrm{p}<.001$

The logit model results showed below in Table 4 demonstrates the relationship between demographic features, occupation and the ability of women to have control over resources, livestock and land. The results displayed by the logit shows that occupation is a vital indicator of control over resources. There is little probability for both unskilled and skilled women working in the agricultural sector to be empowered when in contrast with women in other sectors. Nevertheless, the logit results puts forward a suggestion that for many women, making huge contributions to the income of the family influences resource control than the kind of employer they work for. For example, all women who work in 
the agricultural sector, unskilled or skilled positions and even professionals who work for family or are self-employed have a little chance of having the ability to control their properties, income, or resources. As shown by Table 4, women control over resources is influenced by women's education, age and occupation. Moreover, it is can be seen from the table that, the control variables of income $(\mathrm{OR}=1.78, \mathrm{p}<.01)$, marital status $(\mathrm{OR}=1.37, \mathrm{p}<.01)$ and living in urban areas $(\mathrm{OR}=1.26, \mathrm{p}<.05)$ have higher chance of influencing women's control over resources.

Table 4: Logit Model Predicting Control over Resources by Financial, Demographic and Occupational Characteristics

\begin{tabular}{|c|c|c|c|c|}
\hline Variable & Model 1 & Model 2 & Model 3 & Model 4 \\
\hline \multicolumn{5}{|l|}{ Demographic measures } \\
\hline Primary education (omitted $=$ tertiary) & $.017 * *$ & $.017 * *$ & $.014 * *$ & $.013^{* *}$ \\
\hline Secondary education (omitted $=$ tertiary) & $.723 * *$ & $.715 * *$ & $.706 * *$ & $.701 * *$ \\
\hline Higher education (omitted = tertiary) & $1.55^{* *}$ & $1.52 * *$ & $1.52 * *$ & $1.38 * *$ \\
\hline Age $15-24$ (omitted $=65$-older $)$ & $.168 * * *$ & $.142 * * *$ & $.187 * * *$ & $.116^{* * *}$ \\
\hline Age $25-39$ (omitted $=65$-older $)$ & $.373 * * *$ & $.354 * * *$ & $.351 * *$ & $.376 * *$ \\
\hline Age $40-64$ (omitted $=65$-older $)$ & $.591 * *$ & $.568 * * *$ & $.565 * * *$ & $.539 * * *$ \\
\hline Married (omitted $=$ Single) & $1.37 * *$ & $1.37 * *$ & $1.29 * *$ & $1.14 * *$ \\
\hline Married (omitted= Other) & $1.18 * *$ & $1.09 * *$ & $1.02 * *$ & $.972 * *$ \\
\hline Urban (omitted= Rural) & $1.67 *$ & $1.65^{*}$ & $1.58 *$ & $1.54 *$ \\
\hline Rural (omitted= Urban) & $-.485^{* *}$ & $-.479 * *$ & $-.467 * *$ & $-.429 * *$ \\
\hline Large family size (omitted= otherwise) & $0.162 * *$ & & & \\
\hline Children & $.157 * *$ & & & \\
\hline \multicolumn{5}{|l|}{ Financial Measures } \\
\hline Income & & $1.78 *$ & & $1.17 * * *$ \\
\hline Employed (omitted = unemployed) & & $1.716^{*}$ & & $1.682 *$ \\
\hline Unemployed (omitted = employed) & & $1.17 * *$ & & $1.04 * *$ \\
\hline Housewife (omitted = employed) & & $.472 * * *$ & & $.319 * * *$ \\
\hline $\begin{array}{l}\text { Ownership of property (omitted= } \\
\text { otherwise) }\end{array}$ & & $1.105^{* *}$ & & $1.029 * *$ \\
\hline \multicolumn{5}{|l|}{ Occupations } \\
\hline Not Working & & & Omitted & Omitted \\
\hline Professional/Managerial & & & $.706 * *$ & $.587 * *$ \\
\hline Service & & & $.886^{* *}$ & $.694 * *$ \\
\hline Household & & & $.509 * *$ & $.447 * *$ \\
\hline Skilled manual & & & $.273^{* *}$ & $.197 * *$ \\
\hline Unskilled manual & & & $.099 * *$ & $.076 * *$ \\
\hline Agricultural & & & $.118 * *$ & $.092 * *$ \\
\hline Likelihood ratio $\mathrm{X}$-square & 6.893 & 21.981 & 26.267 & 28,690 \\
\hline$(-2 \log$ likelihood) & 1721,338 & 1463,819 & 1094,485 & 1005,192 \\
\hline Weighted $\mathrm{N}$ & 1450 & 1450 & 1450 & 1450 \\
\hline
\end{tabular}

$* \mathrm{p}<.05, * * \mathrm{p}<.01, * * * \mathrm{p}<.001$ 


\section{FINAL REMARKS}

In our drive of civilization into globalizing our planet into a single village, several tools work together to accomplish anticipated goals. It is often said that gender equality has been a long time reality, but it is equally fact that there is a vehement disparity betwen the theories and reality. So the content of several legal reforms had not played out of the pages of the papers, they are still alien where they ought to function. You wonder where the women really are in top academic positions and governmental seats. There are impeding factors that slow down the liberation of the woman folk. And this slowing down of the emancipation process has taken a rather negative toll of different aspects of the lives of the women from family to social attachments.

We have also found in this research that there is a significant role played by the environment on the empowerment phase as those women in the Urban areas seem to e catching on really quickly with the revolutionary trend compared to those in rural regions. One can easily tie this outcome to the exposure and learnings that those in Urban regions get, that are lacking in the other environments. And as such, they Urban women easily secure top positions in different institutions and get lots of privilleges that their counterpart miss out on. One traditional practise that actually act as friction for improving empowerment is cultural belief systems that do not support gender equality. Some of these traditionals hold at their hearts the idea that women should be totally subordinate to men. This makes the women see themselves less than the men, and so would not be motivated to compete with the men folk in certain areas, and lose out on empowerment and their liberty at large.

It is therefore the opinion of this work that sincere and vigorous implementation of educational policies that will keep women/girls in school much longer, pursuing innovations that will promote women's economic resilience; innovations like microfinance, credit, savings and insurance, legal and social strategies to increase women's access to productive assets and viable employment opportunities will help them overcome barriers to livelihood along with other policies aimed at promoting gender equality is the right path towards women's emancipation in the Turkish context. Insights complex supported

What has been found so far in this study tally significantly with the results of previous reseachers on this topic, although a few fresh courses were charted. We easily see that one correspondence with previous studies is in the active role of socio-economic and demographic parameters in the overall phenomenon of empowerment. Maintaining a single marital status, having attained high academic qualifications, age, and residing in an urban environment have a deep connection with awareness and liberties, higher decision-making activities, and chances of being in charge of resources, and as such are determinants of empowerment. So we should expect more empowerment when we adopt policies that increase the level of girl child education, hosting more seminars on empowerment, and extending the suitable age for marriage. To achieve this empowerment, the best 
way would not be to be an island, although that may be considered when it has to do with private empowerments like resource management say. And women who are into more entrepreneural roles and official jobs actually stand a higher chance of reaching financial empowerment, whereby they manage their funds as well as exhibit liberties at various levels. This is not always the case however, there are exceptions, and in fact situations where women engaged in domestic duties tend to be more financially empowered than their professional counterpart. So it is not an easily comprehensive web that networks employment and empowerment. To really say what level of empowerment a woman has just by enquiring of her job, you would have to include other factors such as the position she holds in her job, what level of fiancial commitment she assumes in her house, and to what degree she has liberty over her finances.

What this paper has done is work through the non-trivial relationship between different parameters that influence empowerment. Emphasis was as well placed on the place of integrating women into the work force as a key step toward empowerment. Nonetheless it must be realized that a tweak in one parameter of empowerment does not empower the woman folk all-round, but in some specific areas only.

\section{REFERENCES}

Betcherman, Gordon, Luinstra, Amy and Ogawa, Makoto. 2001. Labor market regulation: international experience in promoting employment and social protection. Social Protection Discussion Paper 0128, World Bank: Washington, DC.

Ecevit, Yıldiz. 2003: Women's labor and social security, In Bridging the gap in Turkey: A milestone towards \aster socioeconomic development and poverty reduction, ed. Poverty Reduction and Economic Management Unit Europe and Central Asia Region, 73-101, World Bank: Washington.

Editorial. 2012. Kadının bağımsız olabilmesinin bedeli iki kat çalışmak, Milliyet, December. Retrieved from: http://www.milliyet.com.tr/kadinin-bagimsiz-olabilmesinin-pembenar-detay-ask-1806283/

Gündüz, Zuhal Yeflilyurt. 2012. The Women's Movement in Turkey: From Tanzimat towards European Union Membership. Perceptions, 115-134.

Kabeer, Naila, Mahmud, Simeen, and Tanseem, Sakiba. 2011. Does paid work provide a pathway to women empowerment? Empirical findings from Bangladesh. Institute of Developmental Studies, 375: 1-42.

Ilkkaracan, Ipek. 2012. Why so few women in the labor market in Turkey, Feminist Economics, 18(1): $1-37$.

Kalb, Guyonne. 2009. Children, Labour Supply and Child Care: Challenges for Empirical Analysis, Australian Economic Review, Vol. 42, No. 3: pp. 276-99.

Kasnakoğlu, Zeynep and Dayığlu, Meltem. 1997. Female labor force participation and earnings differentials between genders in Turkey, In Westpost Economic Dimensions of Gender Inequality: A Global Perspective, ed. J.M. Rives and M. Yousefi, 95-117, CT: London.

Kızılırmak, Burça. 2005. Labor market participation decisions of married women: evidence from Turkey, Ankara University, September. Retrieved from: http://www.policyinnovations.org/ideas/policy_library/data/01222/_res/id=sa_File1/

King, Elizabeth, and Mason, Andrew. 2001. Engendering Development: Through Gender Equality in Rights, Resources and Voice. Washington, D.C. and New York: The World Bank and Oxford University Press. A World Bank Policy Research Report.

Medel-Anonuevo, Carolyn, and Bochynek, Bettina. 1995. The International Seminar on Women 
Education and Empowerment (PP:5-12). In C. Medel-Anonuevo (Ed.), Women Education and Empowerment: Pathways towards Autonomy. Hamburg: UNESCO Institute for Education.

Olmsted, Jennifer. 2011. Gender and globalization: the Iranian experience: veiled employment. Syracuse UP: 25-52.

Stokeley, Carmichael, and Hamilton, Charles. 1967. Black Power: The Politics of Liberation. New York: Random House.

Stromquist, Nelly. 1995. The Theoretical and Practical Bases for Empowerment (13-22). In C. Medel-Anonuevo (Eds.), Women Education and Empowerment: Pathways towards Autonomy. Hamburg: UNESCO Institute for Education.

Turkish Statistical Institute, Women in Statistics. 2016. Retrieved from http://www.turkstat.gov.tr Tuna, Tulin. 2012. Gender and Modernization in Turkey. International Journal of Learning \& Development, 2(5): 273-288.

UNDP Human Development Report. 2014. Retrieved from http://hdr.undp.org/en/content/human- development-report-2014

World Economic Forum. 2014. The Global Gender Gap Report, 2014. Geneva: World Economic reform, Retrieved from: http://www3.weforum.org/docs/GGGR14/GGGR_CompleteReport_2014.pdf

Yorgun, Pembenaz. 2013. The Women Question and Difficulties of Feminism in Turkey. Journal of Revolutionary Socialist of the Middle East, No: 11.

\section{GENIŞ ÖZET}

$\mathrm{Bu}$ çalışma modern Türkiye'deki kadınların güçlenmesini ve cinsiyet eşitsizliğini araştırmaktadır. Kadınların güçlendirilmesi kavramı, kadınların daha önce bu tür tercihlerinin reddedildiği alanlarda belirli sosyal, ekonomik ve kültürel tercihleri yapma kabiliyetini arttırmayı ifade eder. Bu kavram, zaman içerisinde farklılık göstermekle birlikte ülkeden ülkeye de değişiklik göstermektedir. Mevcut firsatlara ve hizmetlere, kaynak dağılımına ve eşitliğe olan erişimde eşitsizlik görülebilir. Kadınların sosyo-ekonomik ve kültürel gelişimini teşvik etmek ve desteklemek için Türkiye Cumhuriyeti'nin kurulmasından bu yana çeşitli reformlar yapılmıştır. Bu reformlar dahi halihazırda Türkiye'deki toplumsal cinsiyet eşitsizliği önlemeye yada azaltmaya yeterli olmamıştır. Türkiye'de yaşanan bu durumun yakından incelendiğinde, ilkokul eğitiminden daha yüksek kadın sayısının düşük olması ve cinsiyete dayalı şiddetin önlenememesi, siyasette kadın sayısının azlığı ve işgücü piyasasına kadınların katılım oranlarının düşük olmasının başlıca etmenlerin olduğu sonucunu ortaya koymaktadır. Bunun nedeni, yapılan yasa değişiklikleri ile fiili uygulama arasında önemli boşlukların olmasıdır. Bu yasaların fiili olarak hayata geçirilememesinin bir nedeni ise, toplum içerisinde ve aile düzeyinde hüküm süren ve/veya hala aile içindeki önemli bir etkisi olan ataerkil yapıdır. Özetlemek gerekirse bu çalışmada, eğitim politikalarının etkili bir şekilde uygulanmasının kadınların/kız çocuklarının okula devam ettireceği, kadınların ekonomik esnekliğini artırarak sosyal ve ekonomik alanlarda daha etkin olacağı görüşünü ortaya koymaktadır. Kadınların güçlendirilmesi için yapılması gereken en önemli adımlardan bazıları istihdam olanaklarını artırmak için sosyal ve yasal düzenlemeler, ekonomik esnekliğini teşvik edecek ve toplumsal cinsiyet eşitliğini sağlamayı amaçlayan politikaların sadece kağıt üzerinde değil, fiili olarak da uygulanması gerekliliğidir. 